\title{
Resource Use Efficiency of Maize Cultivation in Bahraich District of Uttar Pradesh
}

\author{
Harendra Pratap Singh Choudhri*, G.P. Singh and Supriya
}

Department of Agricultural Economics, N.D.U.A. \& T. Kumarganj, Ayodhya, Uttar Pradesh, India

*Corresponding author: harendra1992chaudhri@gmail.com (ORCID ID: 0000-0001-9343-6273)

Received: $15-06-2019$

Revised: $22-10-2019$

Accepted: 02-12-2019

\begin{abstract}
Study on resource use efficiency in maize cultivation was conducted in Tejwapur block of Bahraich district of Uttar Pradesh. Primary data was collected from 100 respondents including three categories i.e. marginal, small and medium sized sample farms. Purposive cum random sampling technique was applied to draw the sample of respondents. Personal interview method of data collection, tabular and functional analysis was applied to bring the study at final stage. Result of study revealed that maize production shows the stage of decreasing return to scale and MVP indicate further scope to invest on four factors included in the study to achieve the position of optimum resource combination and maximization of the profit.

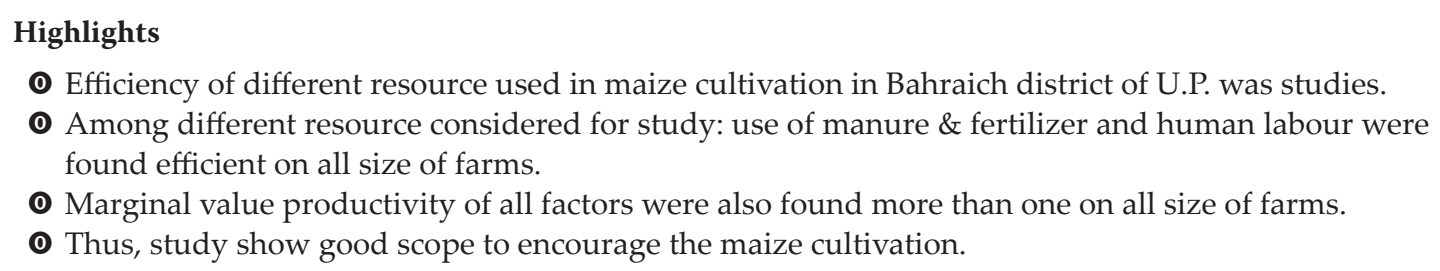

Keywords: Resource, efficiency, MVP, optimum, elasticity

Maize (Zea mays L.) is one of the most important cereal crops in the world agricultural economy both as food for man and feed for animals. It is a miracle crop with very high yield potential. There is no cereal on the earth which has so immense potentiality and that is why it is called 'Queen of Cereals'.

Maize crop is utilized in many ways like other grain crop. Over $85 \%$ of maize produced in the country consumed as human food. Several food dishes including 'Chapattis' are prepared out of maize flour and grains. Green cobs are roasted and eaten by people with great interest. The special variety called 'Pop corn' the grains of which are converted into the popped form is the favorites food for children's in cities and baby corn variety is of great liking of people too. Maize grain contains about $10 \%$ protein, $4 \%$ oil, $70 \%$ carbohydrate, $2.30 \%$ crude fiber, $10.40 \%$ albuminoides and $1.40 \%$ ash. Besides this, it is also a good source of feed and fodder for cattle, poultry and piggery. The green fodder can be fed to milch cattle to boost the milk production to a considerable extent; "South African Maize" is best suited variety for fodder. The crop has to be harvested when the grains are in milky stage, this variety is supposed to have Lactogenic effect hence specially suited for milch cattle. The digestability of maize fodder is higher than sorghum, bajra and other non-leguminous forage crops. Maize plant does not have any problem of hydrogenic acid or prussic acid production, hence if necessary crop can be harvested and fed to cattle at any stage of its growth, of course ideal stage of harvest for green

How to cite this article: Choudhri H.P., Singh G.P. and Supriya (2019). Resource use efficiency of maize cultivation in bahraich district of Uttar Pradesh. Economic Affairs, 64(4): 711-715. 
fodder mid dough stage, when the dry matter content and digestibility are more desirable. The high carotene content of yellow maize is considered to be very useful in imparting yellow colour to egg york and yellow tinge to the milk. No other concentrate is yet known to substitute maize in this respect. Maize stands on second place among all the kharif crops and on third place after rice and wheat among the food grown crops.

Estimation of the technical efficiency of the farmers has revealed that an average sample of farms operate $23 \%$ below the frontier output levels. Hence, it has been observed that the maize output can be increased through adoption of proper technology by the farmers. This requires support from both the state government as well as the private companies (Anupam et al. 2005).

The Cobb-Douglas type of production function was used for functional analysis. The findings of the study showed that the male and female human labour utilization were 77.19 and 106.45 man days per hectare. The bullock labour utilization was 10.68 pair days. The per hectare use of nitrogen was $110.80,110.18$ and $112.10 \mathrm{~kg}$. per hectare in small, medium and large size groups, respectively (Navadkar et al. 2012).

Maize seed has established itself as a very significant component in maize farming system, and determines the cropping pattern of the predominantly peasant farmers. The result of the production function analysis shows that the double log functional form had the best fit to the data, that is $\mathrm{R}^{2}=0.65$, meaning that $65 \%$ of the variation in the output of maize was accounted for by the variables in the model. All the variables in the model had positive regression coefficients indicating direct relationship between each of them and output of maize. The result of the survey also indicated that men had more access to land than women, thus making them to be more involved in maize production in the study area (Onuk et al. 2010).

The returns of scale of the selected inputs were 0.72 and 0.68 for Dinajpur and Panchagarh respectively. The technical efficiency was found on an average 0.84 at Dinajpur and 0.80 at Panchagarh. It was also found that, farmers in the study area had scope to increase maize productivity by attaining full efficiency through reallocating the resources (Faruq et al. 2008).
Reviewing the importance of the crop, it seems necessary to study the efficiency of various inputs used in maize cultivation and find out the marginal value of productivity which may help in deciding the optimum level of resources which can support to maximize the net profit from maize cultivation. Thus after observing the importance of the crop in the cropping pattern a study was conducted in Bharaich district of Uttar Pradesh on resource use efficiency in maize cultivation with the objectives:

1. To study efficiency of various resource used in maize cultivation.

2. To study the marginal value productivity (MVP) of different resources.

\section{METHODOLOGY}

\section{Sampling technique}

Purposive cum random sampling technique was used to select the 100 respondents, from 5 villages of Tejwapur block of Bahraich district. For the further study all selected sample farmers were grouped in three categories of marginal, small and medium size of holdings. To justify the representation of all category of farmers "proportionate random sampling" technique was applied. A sum of 52 marginal, 35 small and 13 medium sizes of sample farms were studied. Details of sampling are presented in Table 1.

Table 1: Village wise proportionate selection of sample farmers under different size group of farms

\begin{tabular}{|c|c|c|c|c|c|c|c|c|c|}
\hline \multirow[t]{2}{*}{$\begin{array}{l}\text { Sl. } \\
\text { No. }\end{array}$} & \multirow{2}{*}{$\begin{array}{l}\begin{array}{l}\text { Size of } \\
\text { farms }\end{array} \\
\text { Name of } \\
\text { Villages }\end{array}$} & \multicolumn{4}{|c|}{$\begin{array}{l}\text { Marginal Small } \\
\text { (below } 1 \text { (1-2 ha.) } \\
\text { ha.) }\end{array}$} & \multicolumn{2}{|c|}{$\begin{array}{l}\text { Medium } \\
\text { (2-4 ha.) }\end{array}$} & \multicolumn{2}{|c|}{ Total } \\
\hline & & $\mathbf{P}$ & $S$ & $\mathbf{P}$ & $S$ & $\mathbf{P}$ & $S$ & $\mathbf{P}$ & $S$ \\
\hline 1 & Maraucha & 45 & 14 & 44 & 13 & 11 & 3 & 100 & 30 \\
\hline 2 & Singhi & 22 & 7 & 13 & 4 & 3 & 1 & 38 & 12 \\
\hline 3 & Raipura & 28 & 9 & 9 & 3 & 2 & 1 & 39 & 13 \\
\hline 4 & Aladadpur & 19 & 6 & 21 & 6 & 9 & 3 & 49 & 15 \\
\hline 5 & Kirtanpur & 52 & 16 & 28 & 9 & 18 & 5 & 98 & 30 \\
\hline \multicolumn{2}{|c|}{ Total } & 166 & 52 & 115 & 35 & 43 & 13 & 324 & 100 \\
\hline
\end{tabular}

Note: $P=$ Population and $S=$ Sample.

\section{Analytical tools}

The data collected from the sample farmers through personal interview with the help of pre- structured 
scheduled were analyzed and estimated with certain statistical techniques like:

\section{Average}

The simplest and important measure of average which has been used into statistical analysis was simple mean and weighted average. The formula used to estimate the average is,

$$
\begin{aligned}
& \bar{X}=\frac{\Sigma X}{N} \\
& \text { Weighted average }=\frac{\Sigma W_{i} X_{i}}{\Sigma W_{i}}
\end{aligned}
$$

Where,

$$
\begin{aligned}
& W \cdot A=\text { Weighted average } \\
& X_{i}=\text { Variable } \\
& W_{i}=\text { Weights of } X_{i}
\end{aligned}
$$

\section{Functional Analysis}

To study the effect of various independent variables on the output, various forms of production function have been dealt. However, Cobb-Douglas function was found best fitted in the data; therefore it was used for measuring resource use efficiency.

The mathematical form of Cobb-Douglas function is:

$$
Y=a X_{1}^{b 1} \cdot X_{2}^{b 2} \cdot X_{3}^{b 3} \cdot X_{4}^{\mathrm{b} 4} \cdot e^{u}
$$

Where,

$$
\begin{aligned}
& Y=\text { per hectare output }(₹) \\
& X_{1}=\text { seed }(₹ / \text { ha) } \\
& X_{2}=\text { Manure and fertilizers }(₹ / h a) \\
& X_{3}=\text { Machinery charge }(₹ / h a) \\
& X_{4}=\text { Total human labour }(₹ / h a) \\
& a=\text { Constant (intercept) } \\
& e^{u}=\text { Error and } \\
& b_{1}, b_{2^{\prime}} b_{3} \text { and } b_{4} \text { production elasticities of the } \\
& \text { respective input variables. }
\end{aligned}
$$

\section{Cobb-Douglas Production function in log form}

$\log Y=\log a+b_{1} \log x_{1}+b_{2} \log x_{2}+b_{3} \log x_{3}+b_{4} \log$ $x_{4} \ldots \ldots . \mu \log e$

This formula was used for estimating the parameters of the function based on sample data.

\section{Marginal Value Productivity (MVP)}

The marginal value product of inputs was estimated by following Formula:

$$
\operatorname{MVP}\left(X_{j}\right)=\frac{b_{j} \bar{Y}}{\bar{X}}
$$

Where,

$$
\begin{aligned}
& M V P=\text { Marginal value product of } j^{\text {th }} \text { input } \\
& b_{j}=\text { Production elasticity with respect to } X_{j} \\
& Y=\text { Geometric mean of the dependent variable } Y \\
& X_{j}=\text { Geometric mean of the independent variable } \\
& X
\end{aligned}
$$

Having estimated the elasticity co-efficient, it is desirable to ascertain the reliability of these estimates. The most commonly used " $t$ " test was applied to know, whether ' $b$ ' is statistically significant from zero or not at some specified probability level.

$$
\text { 't'cal }=\frac{b_{j}}{S . E \text { of } b_{j}}
$$

If calculated ' $t$ ' value is greater than table value of " $t$ " at specified probability level at ' $n-k-1$ ' degree of freedom $b_{j}$ is said to be statistically different from zero.

$\mathrm{F}$ test was used to test the significance of the regression as a whole.

$$
F=\frac{\text { Regression mean square }}{\text { Error mean sqaur }}=\frac{(S S R / K)}{\Sigma e^{2} /(n-k-1)}
$$

Where,

$\mathrm{SSR}=$ sum of square due to regression

$\Sigma e^{2}=$ sum of square of error term

MVP of $j^{\text {th }}$ input factor was tested using the formula.

' $t$ ' $=$ MVPj/S.E. of MVPji

S.E. of MVPj $=\frac{\bar{Y}}{\bar{X}}$ standard erroe of $b_{j}$

\section{RESULTS AND DISCUSSION}

The result of the present study as well as relevant discussion is presented under following sub heads: 
Table 2: Production elasticity of maize crop group on different size group of farms:

\begin{tabular}{|c|c|c|c|c|c|c|}
\hline \multirow[b]{2}{*}{$\begin{array}{l}\text { Size group of } \\
\text { sample farms (ha) }\end{array}$} & \multicolumn{4}{|c|}{ Production Elasticity } & \multirow[b]{2}{*}{$\begin{array}{l}\text { Sum of } \\
\text { elasticities } \\
\text { return to scale }\end{array}$} & \multirow[b]{2}{*}{$\mathbf{R}^{2}$} \\
\hline & $\begin{array}{l}X_{1} \\
\text { (Seed) }\end{array}$ & $\begin{array}{l}X_{2} \\
\text { (Manure \& } \\
\text { Fertilizers) }\end{array}$ & $\begin{array}{l}\mathrm{X}_{3} \\
\text { (Machinery charge) }\end{array}$ & $\begin{array}{l}\mathrm{X}_{4} \\
\text { (Human Labour) }\end{array}$ & & \\
\hline Marginal & $0.051(0.13759)$ & $0.314^{* *}(0.07891)$ & $0.133(0.114)$ & $0.340^{* *}(0.071)$ & 0.839 & 0.889 \\
\hline Small & $0.124(0.181)$ & $0.227^{* *}(0.074)$ & $0.143(0.170)$ & $0.410^{* *}(0.117)$ & 0.905 & 0.902 \\
\hline Medium & $0.292(0.123)$ & $0.102^{* *}(0.077)$ & $0.033(0.072)$ & $0.556^{*}(0.136)$ & 0.985 & 0.954 \\
\hline
\end{tabular}

* Significant at $5 \%$ level of probability ${ }_{*}$ Significant at $1 \%$ level of probability

$x_{1}, x_{2}, x_{3}$ and $x_{4}$ stand for seed, manure \& fertilizers, machinery charge and human labour (₹) respectively.

\section{Resource use efficiency in maize crop}

Resource use efficiency, elasticity of production, return to scale and other qualities of interest in maize crop at different size group of farms are displayed in Table 2. High value of $\mathrm{R}^{2}$ of the fitted function indicates that sufficient and maximum proportion of the total variation in the dependent variable was explained by the included factors in production process.

The four variables viz., seed, manure \& fertilizers, machinery charge and human labour explained $88.90,90.22$ and 95.44 per cent variation in the dependent variable on marginal, small, and medium sized group of farms respectively.

It is indicated in Table 2 that manure \& fertilizers $\left(\mathrm{X}_{2}\right)$ was significantly associated with the dependent variable at 5 per cent level of profitability on marginal, small and medium size group of sample farms, where as another important factor of production i.e. human labour was also significantly associated with dependent variable at 5 per cent level of probability in marginal and small categories of farms and at 1 per cent probability level in medium sized group of farms. Rest of the two factors i.e. seed and machinery charge did not had any significant impact on maize production in the study area.

Returns to scale on marginal, small, and medium sized group of farms were found $0.839,0.905$ and 0.985 respectively, which were less than unity. It is therefore, concluded that cultivation of maize crop is characterized by decreasing returns to scale on all size group of farms of the study area.

\section{Marginal Value Productivity (MVP)of maize crop}

It is clear from Table 3 that the MVP of seed, manure
\& fertilizers, machinery charge and human labour measure were considerably high on all size group of farms except human labour on medium farms and machinery charge on marginal farms. The MVP more than one indicates that there is chance to spent more on additional inputs to receive additional income.

Table 3: Marginal Value Productivity (MVP) of factors in production process of maize crop

\begin{tabular}{lllll}
\hline \multirow{2}{*}{$\begin{array}{l}\text { Size } \\
\text { group of } \\
\text { farms }\end{array}$} & \multicolumn{4}{c}{$\begin{array}{c}\text { Marginal Value Productivity of input / } \\
\text { factors }\end{array}$} \\
\cline { 2 - 5 } & $X_{1}$ & $X_{2}$ & $X_{3}$ & $X_{4}$ \\
\hline Marginal & 1.412 & 2.897 & 0.979 & 1.302 \\
Small & 3.455 & 2.082 & 1.039 & 1.554 \\
Medium & 8.255 & 2.677 & 1.809 & 0.163 \\
\hline
\end{tabular}

$x_{1}, x_{2}, x_{3}$ and $x_{4}$ stand for seed, manure $\mathcal{E}$ fertilizers, machinery charge and human labour (₹) respectively.

It may be concluded that investment on these variable resources may help to attain optimum combination of factors of production in the process of maize production, which fulfills the aim of profit maximization.

\section{CONCLUSION}

Maize is a miracle crop and called 'Queen of the Cereals' because it can be grown in all three season of the year and equally useful for men and animals. Maize is rich in various nutrients and stand on second place among all kharif crops and on third place after rice. Seeing the importance of the crop this survey study was conducted in Bahraich district of Uttar Pradesh applying the purposive cum random sampling technique averages and functional analysis were used to analyse the data presentation of the result. Sample of the respondent were constituted with 52, 35 and 13 per cent of marginal, 
small and medium size group of farm. Result shows that among various factors considered for study $\left(X_{2}\right)$ manure \& Fertilizers, and $\left(X_{4}\right)$ Human Labour were significantly and positively affecting the yield and production was found in decreasing returns to scale. MVP of most of the factors at different categories of farm were found more than one, which shows further scope of more expenditure on those inputs to harvest the most possible maximum yield.

Maize cultivation can be suggest as substitute of rice and wheat crops in resource scarcity condition of the day which mainly includes shortage of natural resource like land and water.

\section{REFERENCES}

Anupama J., Singh R.P. and Kumar Ranjit. 2005. “Technical efficiency in maize production in Madhya Pradesh: estimation and implications." CAB Journal article of Agricultural Economics Research Review; 18(2): 305-315.
Faruq Hasan, M. 2008. “Economic Efficiency and Constraints of Maize Production in the Northern Region of Bangladesh. J. Innov. Dev. Strategy, 1(1): 18-32.

Hamsa, K.R., Srikantha Murthy, P.S., Gaddi, G.M. and Rashmi, K.S. 2017. Resource Use Efficiency in Cultivation of Major Food Crops under Rainfed Conditions in Central Dry Zone of Karnataka. Economic Affairs, 62(2): 321-325.

Navadkar, D.S., Amale, A.J., Gulave, C.M. and Nannaware, V.M. 2012. Economics of production and marketing of kharif maize in Ahmednagar district of Maharashtra State. $C A B$ Journal article Agricultural Situation in India; 69(6): 309-316.

Verma A.R. 2007. Economic of production, resource use efficiency, marketing and constraints of maize in Tirba district Dhar of Madhya Pradesh. Agricultural Marketing; 46(4): 13-22.

V. Karthick V., Thilagavathi M., Surendran A., Paramasivam R. and Balaji, S.J. 2015. Estimation of Resource Use Efficiency and Technical Efficiency of Small Onion Farmers in Tamil Nadu: A Cobb-Douglas and Stochastic Frontier Approach. Economic Affairs, DOI: 10.5958/0976-4666.2015.00057.1. 
